\title{
Research of Market Oriented Hotel Management Talents Training Mode of Higher Vocational Collage
}

\author{
Zhi Zhang \\ Hotel Management College, Wuhan City Vocational College, Wuhan, 430064, China
}

Keywords: Market-oriented; Higher vocational colleges; Hotel management; Professionals

\begin{abstract}
As development of hotel industry in China continue to speed up, the demand of domestic tourist enterprises for hotel management professional talents also continue to increase. Hence, hotel management specialty of higher vocational colleges gradually wins attention from state. When negotiating with such talents, it has a problem that is talent cannot match with demand of enterprises. The reason is that teaching planning of higher vocational colleges fails to meet current status and needs of hotel industry, resulting in that there is no effectiveness in hotel management personnel training and that could not meet needs of social development. Hence, the future development of students who are major in hotel management specialty will be affected. This paper conducts a detailed analysis and discussion on defects of hotel management education in higher vocational colleges and reform methods, aiming at that assist colleges to train high-quality and new hotel management talents who are in line with market requirements.
\end{abstract}

\section{Introduction}

After entering into new century, Chinese national economy enters the new stage of the booming development, resulting in constantly increasing in the quality of peoples' lives. With deepening of cultural and economic exchanges with countries, the scale of Chinese hotel industry also continues to expand. Related tourism organization department expects that the scale of Chinese hotel industry in 2020 will be six times as that of current, which has dramatically increased in hotel management professional talents. Therefore, training of hotel management talents in higher vocational colleges is important part of future development of the national hotel industry. High qualified management personnel hotel is rare in current Chinese talent market. Because educational pattern of higher vocational colleges cannot meet demand of current development of the tourism market, hotel management talents trained by higher vocational colleges could not match actual demand for talent in hotel industry. In other words, higher vocational colleges shall be aware of such problems and find out some effective measurements to promote reform of hotel management talents education of higher vocational colleges and to cultivate hotel management talents to meet development needs, resulting in promoting hotel industry growth.

\section{Problems of Hotel Management Talents Training in Higher Vocational Colleges}

In recent years, many domestic higher vocational colleges conduct innovation on their talents training in a positive way; continue to explore new measures to promote sustainable development of hotel management professional. However, the mismatch problem of hotel management talents education of higher vocational colleges and actual demands of hotel market are still prominent. Several aspects are as below:

First is that training orientation of professionals cannot meet demand of demands of hotel market. Some higher vocational colleges has no clear target orientation of internal hotel management education, or it has a phenomenon that target orientation is too low that is nearly to that of secondary schools or target orientation is too high that is nearly to that of undergraduate colleges. And did not fully understand needed personnel types and professional skills ${ }^{[1]}$. 
Second is that talents training work goes too far away from social requirement. Hotel management professional course of higher vocational colleges has many problems, including outdated teaching methods, lack of lack of effectiveness of the curriculum system, ignoring exercise procedures and shortage of comprehensive teacher talent, etc.

Third is that interactive communication of hotel enterprises and vocational colleges is inadequate. Many higher vocational colleges have a lack of communication and cooperation with the hotel enterprises, resulting in that they have no understand current industry situation and what is hotel enterprises need. Hence, hotel enterprises cannot recognize education of higher vocational colleges.

Fourth is that talent evaluation system is not perfect. Many higher vocational colleges judge professionals by traditional evaluation and assessment methods, namely, performance-oriented. Students can smoothly graduate from college when having qualified score. It pays less attention on student's own professional ethics and operational capability and other implicit factors that could not be judged by score. Such factors are most important professional qualities in the follow-up work in the hotel industry ${ }^{[2]}$.

In short, higher vocational colleges shall ensure their educational method of hotel management specialty match with development need of hotel industry. Or no matter how good market prospect, it would be abandoned by hotel market and future society due to inappropriate teaching planning. Therefore, the hotel talent training of higher vocational colleges shall be reformed and improved according to development demand of current hotel market.

\section{Reform Measures for Talent Cultivation}

\section{Pay Close Attention to the Development of the Hotel Industry, Focusing on Research}

Detailed and comprehensive industry research is innovation measure of college teaching to efficiently promote marketability, sustainability and occupational targeted of talents training work, which is core means to ensure that the core of the training level. Professional industry research can help higher vocational colleges to have a more clear understand of development situation and future prospects of hotel industry and related businesses as well as current structure, needs for capacity and number of professional talents of hotel industry, aiming at that curriculum and teaching mode of hotel management specialty can adapt development needs of whole region, industry and society ${ }^{[3]}$. In addition, it shall understand vocational ability, professional quality and job competency requirements of hotel industry and related enterprises. Taking these requirements as standard, colleges conduct orientation of teaching objectives and guidelines talents of this major. Then, establish a more reasonable professional curriculum system premised on knowledge base, personality characteristics and development needs, theoretical knowledge, skills and professional qualities and other factors of students. The detailed research and thinking shall be conducted on results of the research results, aiming at that the accurate investigation result can be obtain and data with times and effectiveness will be supplied for teaching innovation and improvement.

\section{Conduct targeted research, build up reasonable curriculum system}

To organize experts of teaching and hospitality sector conducts discussion on professional teaching, which is main channel. Conclusion and measures made in discussion is theoretical basis that can help higher vocational colleges to conduct reasonable setting and development of professional curriculum; that can guide higher vocational colleges conduct planning of teaching mode of professional curriculum according to current development needs of hotel industry ${ }^{[4]}$. Therefore, the discussion involving experts from different fields shall be implemented, which has important role in building hotel professional education and promoting development of hotel professional education. These experts have knowledge of professional field, which indicates that they have keen insight on whole market and grasp focus of construction of specialized course system; that they can give detailed course content according to cultivation of vocational ability requirements of professional posts. By doing this, teaching procedure based on students' future career development process will be developed; good and multi-level course system will be built, which can make 
curriculum be in line with reality and improve effectiveness of student learning. Such professionals trained by higher vocational colleges can meet needs of current enterprises. Only improve the overall quality of the students and promote coordination of talent and enterprise markets can be accepted by enterprises on professional education.

\section{Strengthen training; improve students' professional skills proficiency}

Close cooperation with related enterprises can ensure that teaching content and teaching method is in line with needs of industry, which indicates that higher vocational colleges can cooperation with hotel enterprises on teaching resources and job resources. Teaching resources refer to content related with students' theoretical knowledge and information. For example, higher vocational colleges can invite hotel enterprises to prepare professional materials and teaching programs. Relying on specialty and epochal character of hotel enterprises, the advancement of textbook content can be improved that makes a good connect teaching materials with needs of current hotel industry and make students learn knowledge could be used in subsequent employment process ${ }^{[5]}$. In addition, colleges can introduce industry magazines, newspapers and literatures related with hotel industry, which can let students know latest trends and information of hotel industry and can help students to plant their learning objectives in a targeted way. Job resources refer to cooperation of practical aspects. Only make student access to hotel's employment experience can cultivate professional hotel management talent who meet needs of hotel industry, which can ensure students to clear recognition for their own future work, to make a clear positioning itself, to be familiar with the working environment, to accumulate related work experience and improve their professional competence and professional quality. Overall, corporate site visits and experience link in school can effective help student to improve actual operation ability and well know enterprises and market. Such short-term practice could not make students work directly after graduation. It is necessary that higher vocational colleges let students conduct in-depth and concentrated practice before graduation. For example, colleges can arrange students work as intern for six months before graduation, which can ensure that students know enterprise internal structure, experience process of gradually turned into "professionals", improve their professional skills and strengthen their own problem-solving capacity. In this process, we should focus on strengthening the practice bases and set up, must choose a representative, with the hotel industry advanced level of business entities, to be able to establish a partnership to ensure that students can enrich the cultural heritage , can learn skills and knowledge of the work environment, and gradually to the hotel management and workflow concepts have a more profound understanding and grasp, cultivate a good professional qualities, skills and knowledge and learn better during operation in to use to enhance their efficiency and competitiveness. Such resources cooperation, both for the hotel industry, or for college, is a win-win double benefit, in favor of the future development of both sides.

\section{Strengthening teaching staff and ensure the quality of teaching}

The teaching implementer of each college and each major is important core factor that determines the teaching achievements eventually, while such teaching implementer is teachers of college. Only high qualified teachers who have rich specialized theoretical knowledge and adequate business experience can conduct teaching process of hotel profession effectively and ensure effectiveness of teaching and provide stable solid base for cultivation of application-oriented, practical talents. However, current teachers of hotel management specialty has no sufficient practical experience in the hotel industry and only conduct teaching according to book. Therefore, higher vocational colleges shall build practical and interactive excellent teachers firstly, which can ensure that they can cultivate students who are meet market demand. Colleges and universities shall actively encourage teachers to conduct practical training in hotel industry via taking a temporary post, which can improve teachers' professional knowledge and practice application ability. By doing this, the teachers can have rich theoretical knowledge and strong practical application and coaching ability. In addition, the teachers shall fully understand developments and future trends of current hotel industry, which can convenient to improve teaching contents according to practical situation and spread industry information with epochal character and practical value to students. Secondly, colleges can invite professional who 
have rich practical experience as professional teacher to conduct targeted guidance. Finally, colleges shall organize teachers to attend AC Conferences \& Training related with industry knowledge, which can ensure students accept more specialized knowledge.

\section{Build a career oriented evaluation system}

Evaluation and assessment standard of hotel management specialty of higher vocational colleges shall conform to that of hotel for internal talents. Taking market demand as standard, hotel management education of higher vocational colleges shall conduct reform of traditional evaluation methods and develop a more effective evaluation mode. The integration of enterprises' assessment and colleges' assessment can be highlighted according to characteristics of higher vocational education and demand of market development in future. Accurate, fair and professional skills audit and capacity evaluation system shall be built. Assessment methods and reference of actual teaching achievements of college shall be reformed. The content, form and result of evaluation can be improved on the basis of cultivation of professional skill. Focus on strengthening the assessment system reform and focus on test and evaluation of students' practical ability. Meanwhile, the core of assessment is professional skill and the guidance of assessment process is evaluation system. Conduct reform on traditional evaluation methods, forming audit system integration of practice evaluation and theoretical knowledge evaluation. Curriculum model shall adopt open education model curriculum that integrate ordinary assessment with summative evaluation and integrate theoretical knowledge training and oral examination and vocational skills training to ensure more enrichment teaching evaluation system.

\section{Conclusion}

All in all, the good development of hotel management specialty of higher vocational colleges can be achieved via strengthening real-time dynamic of hotel industry and taking current market development need as guidance for teaching work. The way of talent training shall be improved appropriately to ensure that meet needs of era development. In addition, ideological quality training and influence of the ideological quality of students shall be further strengthened, which can make students adapt to hotel industry and related positions. Personnel training methods linked with society shall be constantly found, which can cultivate more qualified people.

\section{References}

[1] Ni Xiaoli, Research of Market-oriented Hotel Management Vocational Training Mode of Higher Vocational Colleges . Oriental Enterprise Culture, 2014

[2] Zhou Zhihong. Research of Market-oriented Hotel Management Vocational Training Mode of Higher Vocational Colleges-Taking Huatian Hotel and Tourism Management Institute as example. Hunan Normal University, 2009. Zhou Zhihong.

[3] Wang Miaomiao. Research of Market-oriented Hotel Management Vocational Training Mode at Undergraduate Degree. Qingdao University, 2011.

[4] Li Changqiu. Current Situation and Countermeasures of Hotel Management Vocational Training Mode of Higher Vocational Colleges . Vocational Education Research, 2011(3):27-28.

[5] Zhou Danong, Zhou Li. Thinking about Creative Talents Cultivation of Hotel Management Specialty of Higher Vocational Colleges. Education and Vocation, 2012(12):108-110. 